\title{
The Asian fish tapeworm Schyzocotyle acheilognathi is widespread in baitfish retail stores in Michigan, USA
}

\author{
Traimat Boonthai ${ }^{1}$, Seth J. Herbst ${ }^{2}$, Gary E. Whelan², Michelle Gunn Van Deuren ${ }^{1}$, Thomas P. Loch ${ }^{1}$ \\ and Mohamed Faisal ${ }^{1,3^{*}}$ (D)
}

\begin{abstract}
Background: The Asian fish tapeworm Schyzocotyle acheilognathi (Yamaguti, 1934) is an important fish pathogen because of its wide range of intermediate and definitive hosts and its pathological consequences. This study was designed to determine if baitfish are a likely vector contributing to the expansion of the invasive Asian fish tapeworm.

Results: We collected live baitfish for examination from 78 retail stores in Michigan between September 2015 and June 2016. A total of 5400 baitfish (90 lots, 60 fish/lot) were examined, including 42 emerald shiners [Notropis atherinoides (Rafinesque, 1818)] lots, 30 fathead minnow [Pimephales promelas (Rafinesque, 1820)] lots, 11 golden shiners [Notemigonus crysoleucas (Mitchill, 1814)] lots, 3 sand shiners [Notropis stramineus (Cope, 1865)] lots, 1 lot each of spottail shiners [Notropis hudsonius (Clinton, 1824)], Northern redbelly dace [Phoxinus eos (Cope, 1861)], and blacknose dace [Rhinichthys atratulus (Hermann, 1804)] and 1 lot of mixed two species: weed shiners [Notropis texanus (Girard, 1856)] and sand shiners.

Conclusions: Based on its scolex and strobilar morphology combined with gene sequence analysis, S. acheilognathi was only found in emerald shiners, golden shiners and sand shiners. The mean within lot prevalence and abundance of infection was highest in emerald shiners (20.3 \pm 14.0 and $1.15 \pm 1.34$ ), followed by golden shiners $(8.3 \pm 10.7$ and 0 . $89 \pm 1.27)$ and sand shiners $(1.3 \pm 2.6$ and $0.02 \pm 0.05)$. However, the mean intensity of S. acheilognathi in emerald shiners was lower ( $4.3 \pm 2.6)$ than that of golden shiners $(6.6 \pm 6.7)$. S. acheilognathi-infected fish exhibited enlargement of the abdomen, distension of the intestinal wall, and intestinal occlusion and hemorrhage. This finding suggests that live baitfish are a likely vector by which the invasive Asian tapeworm's range is expanding.
\end{abstract}

Keywords: Baitfish, Vector, Asian fish tapeworm, Cyprinids, Great Lakes

\section{Background}

Aquatic invasive species and pathogens have plagued the Laurentian Great Lakes region for decades [1] and new introductions and further spread of established non-native organisms continues to be a significant threat to native communities. Detrimental aquatic organisms and pathogens have historically been introduced through numerous pathways including commercial shipping, dispersal, live baitfish trade, and stocking [2]. The risk associated with the various

\footnotetext{
* Correspondence: faisal@cvm.msu.edu

'Department of Pathobiology and Diagnostic Investigation, College of Veterinary Medicine, Michigan State University, East Lansing, MI 48824, USA ${ }^{3}$ Department of Fisheries and Wildlife, College of Agriculture and Natural Resources, Michigan State University, East Lansing, Ml 48824, USA Full list of author information is available at the end of the article
}

pathways is dynamic and gaining an understanding of the potential for invasive species and pathogens to be introduced into the landscape is critical for informed management. The live baitfish trade, for example, has been highlighted as high risk for introducing aquatic invasive species $[3,4]$. The live baitfish trade pathway has limited documented evidence related to the potential to spread or introduce harmful invasive pathogens and parasites with viral hemorrhagic septicemia virus (VHSv) being a prime exception [5, 6], and the need to inspect this pathway for fish health threats is critical. Gaining information on these threats would allow managers to mitigate potential risks to reduce future ecosystem challenges resulting from new introductions. 
In the Great Lakes region, the spread of the invasive Asian fish tapeworm, Schyzocotyle acheilognathi (Yamaguti, 1934) Brabec, Waeschenbach, Scholz, Littlewood \& Kuchta, 2015 (Cestoda: Bothriocephalidae) (formerly Bothriocephalus acheilognathi [7]) is a great concern among managers. Schyzocotyle acheilognathi is a generalist invasive fish parasite that can cause substantial mortality in infected fish. Fish serve as the final host for S. acheilognathi, where it reaches sexual maturity in the intestinal tract and can cause significant damage in the form of intestinal occlusion, pressure necrosis, and even intestinal perforation and rupture (reviewed in [8]). Controlling the dissemination of this parasite is complicated by its two-host life-cycle between fish and cyclopoid copepods. Over 200 fish species of different families are known to serve as a definitive host [8] and the intermediate host role is played by various cyclopoid species that have very wide geographical ranges [9]. Schyzocotyle acheilognathi is indigenous to East Asia and was reported in the USA for the first time in 1975 [10]. This parasite has since spread to multiple states and watersheds $[11,12]$ where it threatens some endangered and threatened wild fish species [13, 14], as well as farmed fish [15].

Cyprinid fish species are particularly susceptible to $S$. acheilognathi parasitism, and there are increasing concerns that small freshwater cyprinids are contributing to the rapid expansion of $S$. acheilognathi in North America due to their extensive use in the baitfish trade. In this context, studies of Muzzall et al. [12] and Macrogliese et al. [16] demonstrated that several of the Great Lakes wild cyprinid species commonly used as baitfish harbor S. acheilognathi, which led the authors to conclude that the live baitfish trade may constitute a key pathway by which the parasite can increase its geographical range not only in the Great Lakes, but also to inland lakes, other waterways, and potentially to aquaculture facilities. In samples collected from six baitfish retail stores in Canada, Macrogliese et al. [16] detected S. acheilognathi, illustrating the broad spatial scope of this harmful non-native parasite.

In Michigan, the baitfish industry supports a multi-billion dollar sport fishery [17] and contributes over \$20 million annually to Michigan's economy (Michigan DNR, unpublished data). The business approach of this industry entails moving minnows from source waters to holding facilities and then to retailers using a variety of supply chains. The supply networks provide a potential vector to move invasive pathogens quickly to widely distributed waters. The majority of baitfish sold in Michigan are harvested from wild sources within the state. Specifically, the in-state catch is primarily composed of emerald [Notropis atherinoides (Rafinesque, 1818)] and spottail [Notropis hudsonius (Clinton, 1824)] shiners with lesser numbers of white suckers [Catostomus commersonii (Lacépède, 1803)] and sand shiners [Notropis stramineus (Cope, 1865)]. Capture locations for these wild minnows include shoreline locations in Saginaw Bay (Lake Huron), along Lake Huron, and the St. Clair River. In-state minnows are collected in November/December to support ice-fishing activities and again in April/May to support yellow perch [Perca flavescens (Mitchill, 1814)] fisheries in the spring. A lesser amount of emerald shiners and white suckers are also imported from wild sources originating from the Wisconsin River in Wisconsin. In addition, minnows in retail baitfish shops during the period from May to November are imported from other states, mainly from aquaculture operations in Arkansas, Minnesota, South Dakota and North Dakota, along with lesser amounts from wild harvest from the Wisconsin River in Wisconsin. Most of Michigan's imported minnows from aquaculture facilities are fathead minnows [Pimephales promelas (Rafinesque, 1820)], golden shiners [Notemigonus crysoleucas (Mitchill, 1814)], and white suckers along with a smaller number of wild-caught emerald shiners and white suckers originating from waters in Wisconsin.

In general, most of the wild-caught minnows from Michigan waters are sold in the Lower Peninsula. Wild-caught emerald shiners and white suckers, mostly from Wisconsin waters, are generally sold in the Upper Peninsula. Currently, Michigan regulations prohibit the export of any wild-caught bait. Imported minnows from aquaculture facilities can be found nearly anywhere in the state. All in-state emerald shiners, spottail shiners and white suckers are inspected for VHSv and all imported minnows are inspected for $\mathrm{VHSv}$ and Heterosporis sp. While fish health inspections are conducted for some pathogens and parasites for specific baitfish species, currently there are no inspections to determine the presence of the non-native $S$. acheilognathi in the baitfish trade. Therefore, a need to determine the prevalence of $S$. acheilognathi exists and needs to be addressed to help determine if a significant risk of spread through the baitfish trade exists in Michigan.

The purpose of this study was to determine the extent to which the Asian fish tapeworm, S. acheilognathi, is found in the baitfish supply chain in Michigan. Given the potential damage this parasite could cause from the indiscriminate movement across the state from baitfish, this information will be used to develop new management and range expansion prevention tools.

\section{Methods}

\section{Fish and sample collection}

One to two lots of baitfish, each lot constituting 60 fish of single species, were anonymously purchased from retail stores $(n=78)$ throughout Michigan by the Michigan Department of Natural Resources personnel (Fig. 1). The retail stores sampled were randomly selected from a list of all licensed baitfish shops in Michigan. In addition, 


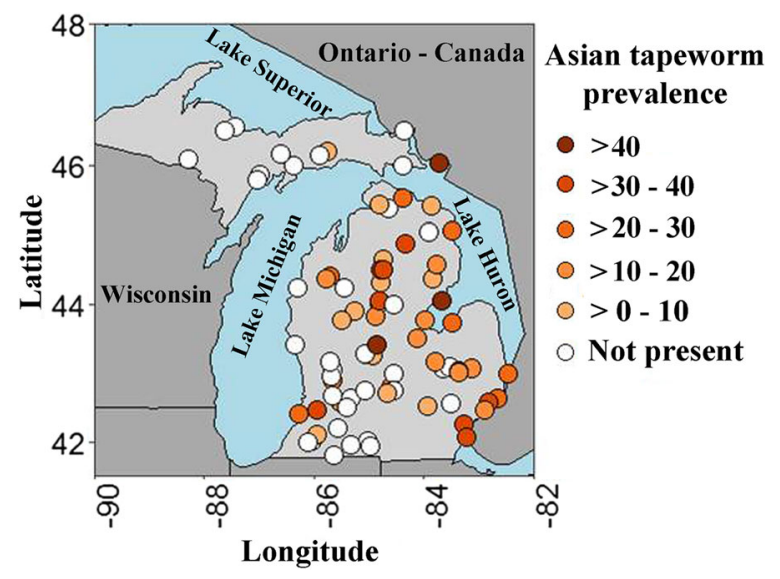

Fig. 1 Map showing the geographical locations of sampling sites and prevalence of the Asian fish tapeworm Schyzocotyle acheilognathi prevalence at each location sampled

the baitfish lots purchased during each sampling event were later categorized as originating from an in-state or out-of-state collection source based on post-hoc personal communications with individual baitfish shop owners. The source categories were used to determine the effect that importing or exporting baitfish would have on the introduction or spread potential of $S$. acheilognathi. The majority (76/78) of baitfish stores kept their tanks indoors, while two stores have their tanks outdoors at the time of sample collection.

During the course of this study from September 2015 to June 2016, a total of 5400 baitfish (90 lots total) of the family Cyprinidae were examined, including 42 emerald shiner lots, 30 fathead minnow lots, 11 golden shiner lots, 3 sand shiner lots, and 1 lot each of spottail shiner, northern redbelly dace [Phoxinus eos (Cope, 1861)], and blacknose dace [Rhinichthys atratulus (Hermann, 1804)]. In one case, 60 fish of a single species were not available, and thus were replaced by 30 weed shiners [Notropis texanus (Girard, 1856)] and 30 sand shiners. Fish species were identified based on their original description and nomenclature was updated using FishBase (http://www.fishbase.org).

After purchase, baitfish were transported live to the Michigan State University, Aquatic Animal Health Laboratory (MSU-AAHL), where they were examined for the presence of abnormal behavioral and clinical disease signs within $24 \mathrm{~h}$ of collection. Next, fish were euthanized with $250 \mathrm{mg} / \mathrm{l}$ of sodium bicarbonate-buffered tricaine methane sulfonate (MS-222, Argent Chemical Laboratories, Ferndale, Washington, USA), dissected using separate sterile scissors and forceps for each fish, and examined for the presence of internal gross lesions. Last, the entire gastrointestinal tract from each fish was examined for the presence of cestodes according to USFWS and AFS-FHS [18] protocol. Gastrointestinal tracts of small fish were placed directly on a microscope slide, visceral organs removed, and then covered with another glass slide. For larger fish, contents of the gastrointestinal tracts were gently removed to keep cestode scolices intact and then spread and flattened between two microscope slides. All slides were then examined under a dissecting microscope and/or a light microscope.

\section{Parasitological examination and morphological identification of S. acheilognathi}

Tapeworms with pyramidal-shaped scolices were further distinguished based on their anatomical features $[10,11,19]$. Mature cestodes were morphologically identified as S. acheilognathi if they displayed: (i) a pyramidal-shaped, flattened scolex that lacked hooks and suckers but had two elongated bothria; (ii) a segmented strobila; (iii) no distinct neck (i.e. the non-segmented region behind the scolex area and anterior to the first obvious segment); and (iv) a posterior portion of the scolex that was clearly wider than the anterior segmented strobila. Cestodes matching these morphological criteria were then placed in $70 \%$ ethanol for subsequent confirmatory molecular identification and enumeration.

\section{Molecular identification}

Representative specimens that: (i) matched the morphological characteristics of S. acheilognathi; (ii) were recovered from multiple host species (e.g. emerald shiner, golden shiner and sand shiner); and (iii) were collected from baitfish vendors in different counties and watersheds were selected for further molecular identification. A piece of strobila (mature) or the entire tapeworm (immature) was soaked in TE buffer for $2 \mathrm{~h}$ on a shaking platform $(200 \times \mathrm{rpm})$ to remove ethanol residue. Total genomic DNA was extracted using a DNeasy ${ }^{\circ}$ Blood \& Tissue Kit (Qiagen, Ref. no. 69506, Hilden, Germany) following the manufacturer's protocol and then stored at $-20{ }^{\circ} \mathrm{C}$. Extracted DNA was quantified using a Qubit fluorometer (Invitrogen, Eugene, Oregon, USA) and then diluted to a concentration of $30 \mathrm{ng} / \mu \mathrm{l}$ for polymerase chain reaction (PCR) analysis. The near-complete internal transcribed spacer region (ITS1-5.8S-ITS2; approximate size of $1.4 \mathrm{~kb})$ was PCR-amplified using the primers BD1 (5'-GTC GTA ACA AGG TTT CCG TA-3') and BD2 (5'-TAT GCT TAA RTT CAG CGG GT-3') [20, 21]. Each $25 \mu \mathrm{l}$ PCR reaction was comprised of $12.5 \mu \mathrm{l}$ of $2 \times$ GoTaq Green Master Mix (Promega, Madison, Wisconsin, USA), $0.8 \mu \mathrm{M}$ of each primer, nuclease-free water, and approximately 30 $60 \mathrm{ng}$ of DNA template. PCR amplification was performed in a GeneAmp PCR System 9700 (AB Applied BioSystems, Singapore) using a single denaturation step at $94{ }^{\circ} \mathrm{C}$ for $5 \mathrm{~min}$, followed by 35 cycles of $94{ }^{\circ} \mathrm{C}$ for $30 \mathrm{~s}, 56^{\circ} \mathrm{C}$ for $30 \mathrm{~s}$ and $72{ }^{\circ} \mathrm{C}$ for $45 \mathrm{~s}$, with a final extension period of $7 \mathrm{~min}$ at $72{ }^{\circ} \mathrm{C}$. Amplicons were checked visually by electrophoresis in $1.5 \%$ agarose gel containing SYBR safe (Invitrogen) under UV transillumination (UVP, 


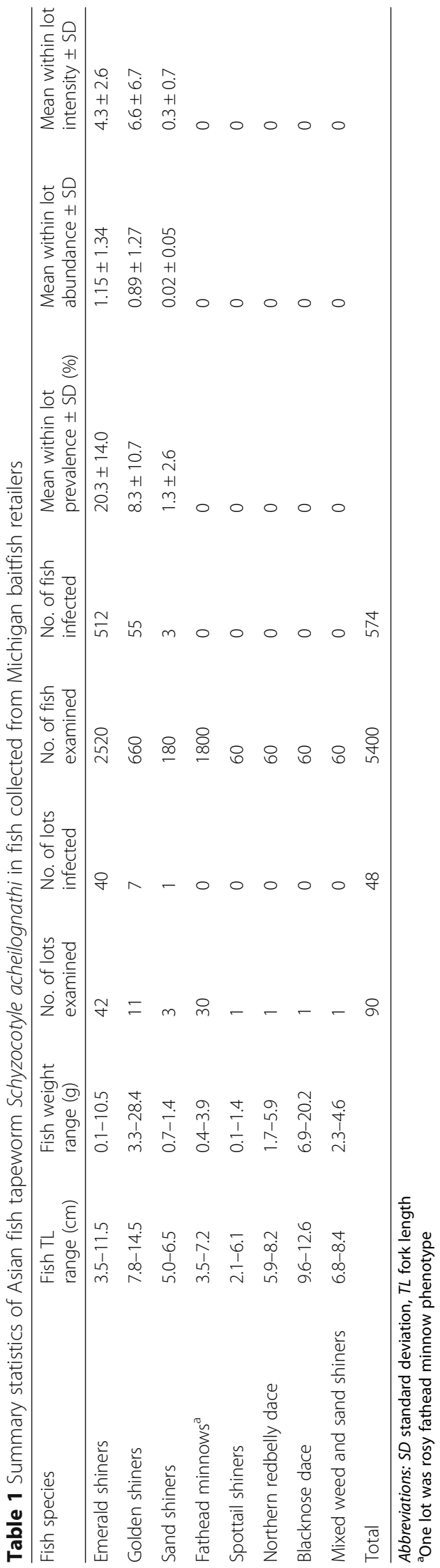


Model TFM-26, Upland, California, USA). Next, amplicons were cloned into chemically competent E. coli (TOPO TA Cloning kit, Invitrogen, Catalog no.: K4575 J10, Carlsbad, California, USA) according to the manufacturer's instructions and then transformants were used for further PCR-amplification using the M13 forward (5'-GTA AAA CGA CGG CCA G-3') and M13 reverse (5'-CAG GA AAC AGC TAT GAC-3') primers. Amplicons were again visually checked by electrophoresis, purified with the Wizard ${ }^{\circ}$ SV Gel and PCR Clean-Up System (Promega, Ref. no. A9281, Madison, Wisconsin, USA), and then sequenced bi-directionally at the Michigan State University, Research Technology Support Facility. Sequencing chromatograms were assembled and edited using BioEdit version 7.1.3.0 [22]. Using the BLAST program [23], sequence data were compared to other cestode sequences, as well as to $S$. acheilognathi sequences from the studies of Brabec et al. [7] and Luo et al. [21] deposited in the National Center for Biotechnology Information (NCBI) database. The sequences of S. acheilognathi generated in this study were deposited in GenBank under the following accession numbers: KY711155-KY711166.

\section{Phylogenetic analysis}

Sequence data from this study were aligned with one another and S. acheilognathi reference sequences using ClustalW in Molecular Evolutionary Genetics Analysis software (MEGA, version 6.0) [24] and then model selection for phylogenetic reconstruction was performed in MEGA 6.0, whereby the model with the lowest Bayesian information criterion (Tamura-Nei model with gamma distribution) was selected. Neighbor-joining analysis [25] was then conducted (MEGA 6.0) using the complete deletion option (total of 1124 informative sites) and topology robustness was assessed via bootstrap analysis $(n=1000$ resamplings).

\section{Statistical analyses}

In this study, we used the definitions of Bush et al. [26] for prevalence (number of infected fish of one species divided by the total number of fish examined of the same species), abundance (total number of tapeworms in a fish species divided by the total number of fish examined of the same species), and mean intensity (the average number of tapeworms in a single fish host).

We used an analysis of variance (ANOVA) to determine if response variables differed among baitfish species collected throughout Michigan's baitfish shops. Response variables included prevalence, abundance, and intensity of $S$. acheilognathi. We used the same statistical analysis to determine if response variables differed by the source or origin of where the baitfish were collected. For this analysis we had two predictor variables, which included in-state and out-of-state sources. When significant differences were detected we then used a post-hoc Tukey's highly significant difference (HSD) test [27] to determine pairwise differences in mean abundance, prevalence, and intensity among the various baitfish species collected.

\section{Results}

Baitfish were obtained between September 2015 and June 2016 from 78 randomly selected baitfish retail vendors throughout the State of Michigan (67 shops in Lower Peninsula and 11 shops in Upper Peninsula; total of 5400 baitfish; Fig. 1). Based on morphological identification combined with gene sequence analysis, S. acheilognathi was identified in emerald, golden and sand shiners, but not in any fathead minnow, spottail shiner, northern redbelly dace, blacknose dace, or weed shiner lots that were examined in this study (Table 1).

\section{Asian fish tapeworm identification}

The anterior portion of intestine was the site where $S$. acheilognathi was attached to the intestinal walls, whereas their bodies extended throughout the entire length of the intestine. Infected fish exhibited enlarged, distended abdomens, whereby worms were frequently visible with the naked eye through the transparent alimentary canal wall (Fig. 2a). Some infected fish also showed hemorrhages within the intestinal wall (Fig. 2b).

Both immature and mature S. acheilognathi were recovered from the intestine of emerald, golden and sand shiners.

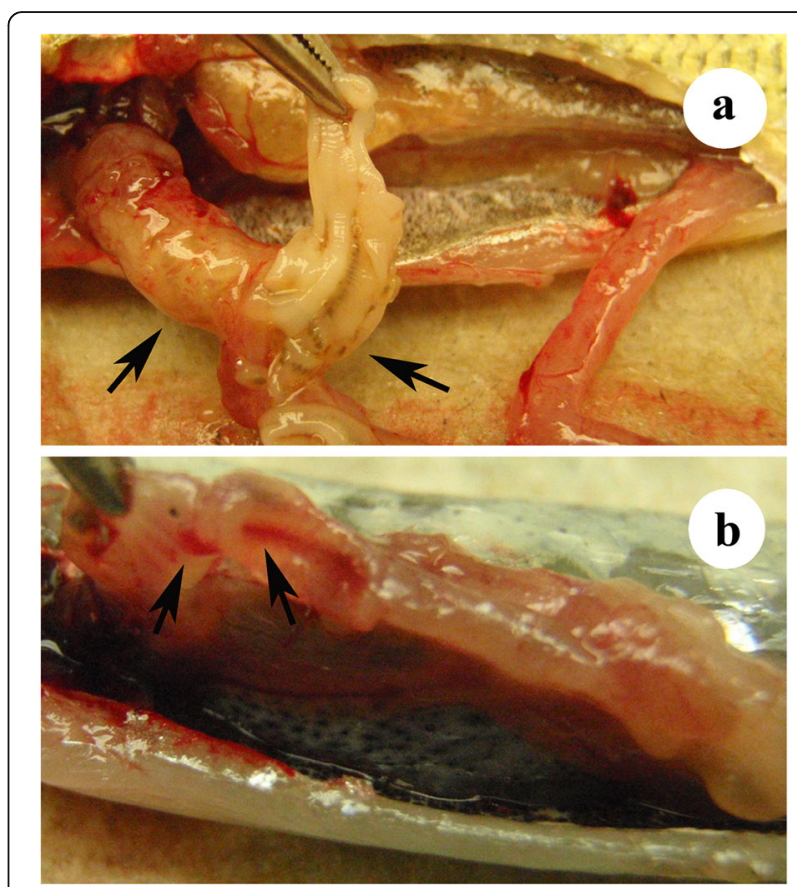

Fig. 2 Schyzocotyle acheilognathi in the intestine of baitfish. a Golden shiner (Notemigonus crysoleucas) exhibiting distended, transparent and occluded intestine (arrows). b Emerald shiner (Notropis atherinoides) exhibiting transparent intestine with hemorrhage (arrows) 
The mature S. acheilognathi were identified based upon the presence of a scolex lacking suckers but with two bothria (Fig. 3a, b), the absence of a distinct neck, segmentation of the strobila (Fig. 3c), and the presence of a scolex that was wider than the anterior portion of the strobila (Fig. 3a, b). Frequently, the gravid proglottids at the distal portion of the strobila were filled with eggs (Fig. 3d). Immature $S$. acheilognathi individually varied in their development ranging from worms with a poorly developed scolex and a non-segmented body (Fig. 3b), to worms with a well-developed scolex with their segments containing non-developed reproductive organs. The majority of $S$. acheilognathi found in this study were immature. Gravid worms were found in 16 emerald shiners from 9 out of 40 infected lots purchased from November 2015 to February 2016 and in 14 golden shiners from 7 infected lots purchased during September to November 2015 and May 2016.

A near complete stretch of the ITS1-5.8S-ITS2 region for 12 representative specimens retrieved from the three fish species in the course of this study confirmed their identity of $S$. acheilognathi. As depicted in Fig. 4, the baitfish $S$. acheilognathi sequences fell within the well-supported clade comprised of $S$. acheilognathi reference sequences that were recovered from multiple geographical locations (e.g. South Africa; Texas, USA; Hawaii; Mexico; the Czech Republic; China; Honduras; Japan; the United Kingdom; Ethiopia; and Turkey). However, within S. acheilognathi clade, some genetic heterogeneity was noted, albeit slight as evidenced by the relatively small genetic distances between the sequences (Fig. 4).

\section{Presence of S. acheilognathi in Michigan retail baitfish shops}

Schyzocotyle acheilognathi was regularly detected in baitfish collected from bait shops throughout Michigan (Fig. 1). Specifically, 48 of 90 (53.3\%) lots examined resulted in the presence of $S$. acheilognathi (Table 1), with the majority of the positive samples (58.2\%) originating from retail shops in the Lower Peninsula and a lower percentage $(18.2 \%)$ of positive samples collected from baitfish shops in the Upper Peninsula.

The prevalence of $S$. acheilognathi was variable throughout the state (Fig. 1) and significantly differed among the
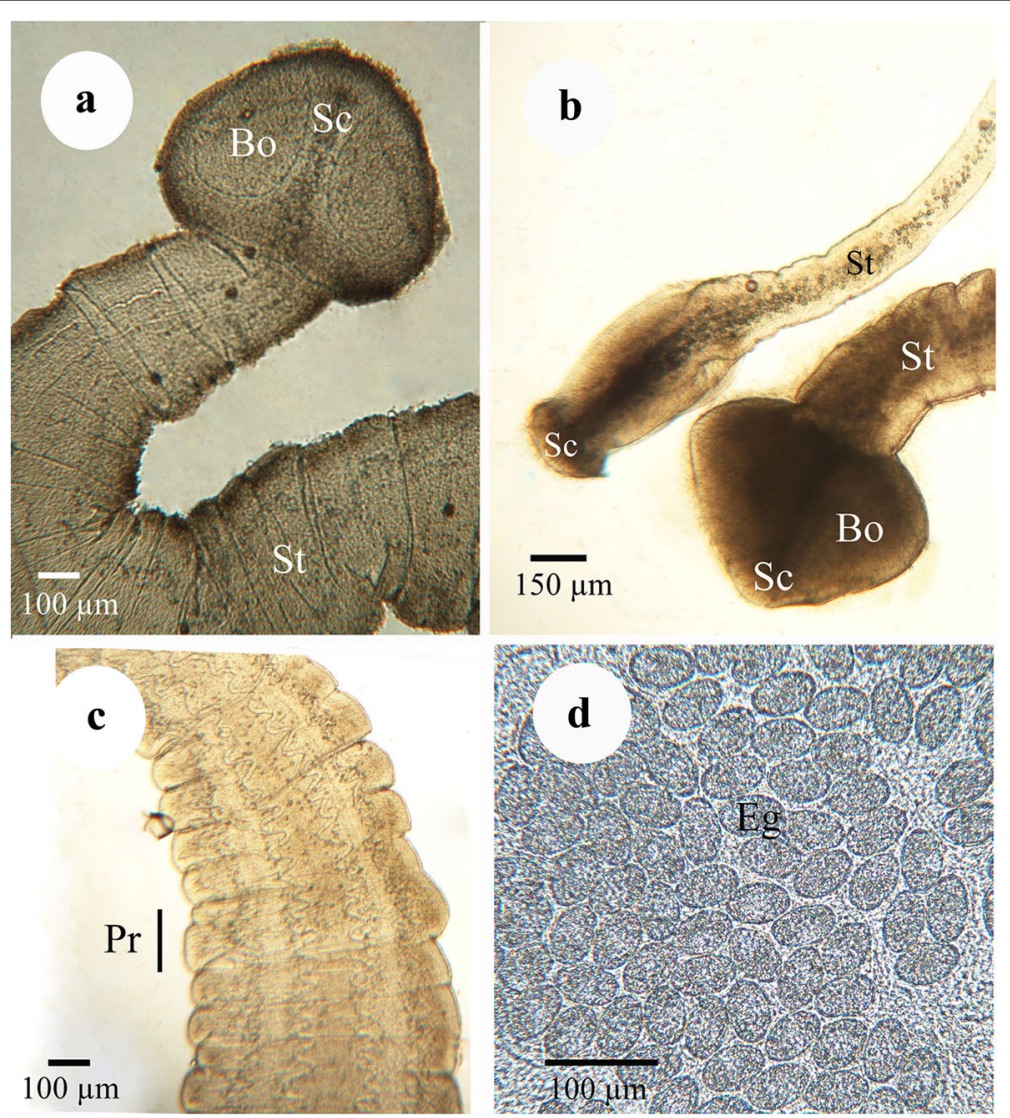

Fig. 3 Light microscope micrographs of the Asian fish tapeworm Schyzocotyle acheilognathi. a Mature S. acheilognathi: note pyramidal-shaped scolex (Sc), bothria (Bo) and strobila (St). b Mature and immature S. acheilognathi found concomitantly in emerald shiner (Notropis atherinoides; identity of both worm stages was confirmed by gene sequence analysis). c Mature segmented strobila (St) with proglottids (Pr) of S. acheilognathi found in emerald shiner. $\mathbf{d}$ Eggs (Eg) within proglottid of S. acheilognathi found in golden shiner (Notemigonus crysoleucas) 


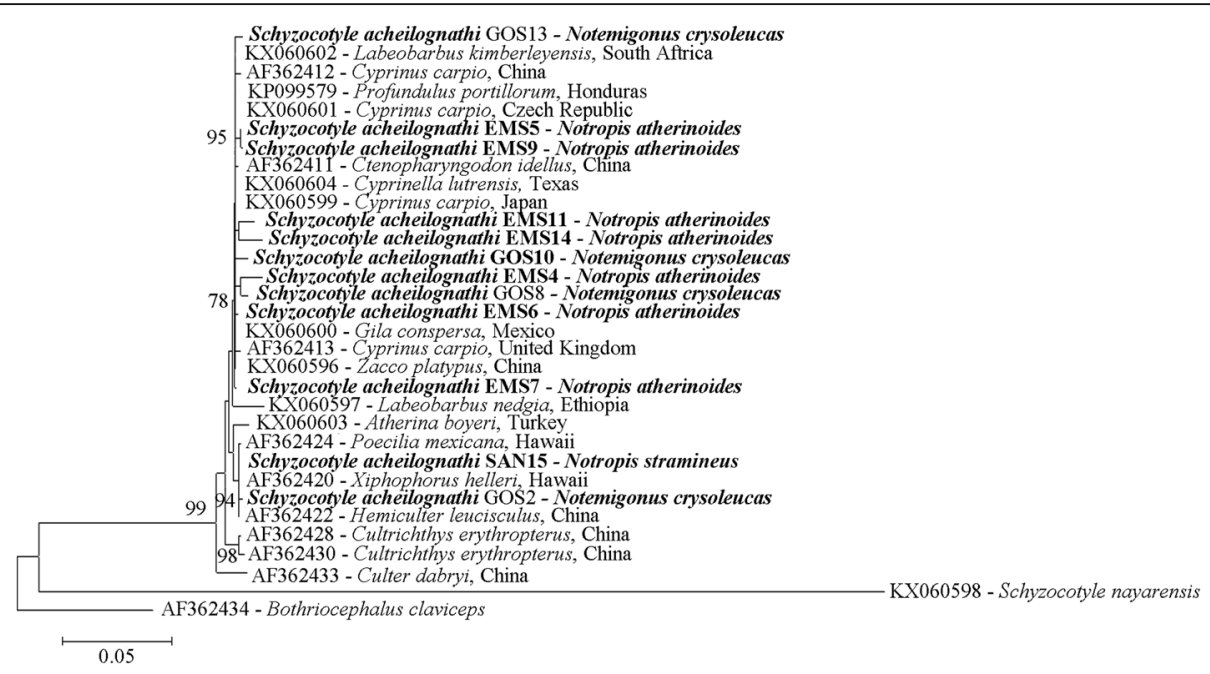

Fig. 4 Dendrogram depicting the relationships of twelve cestodes. Cestodes recovered from emerald shiner (Notropis atherinoides), golden shiner (Notemigonus crysoleucas) and sand shiner (Notropis stramineus) that were collected from baitfish in Michigan were compared to 20 reference sequences (18 Schyzocotyle acheilognathi reference sequences, 1 Schyzocotyle nayarensis sequence, and 1 Bothricephalus claviceps sequence as an outgroup). The internal transcribed spacer region (ITS1-5.8S-ITS2) with approximate size of $1.4 \mathrm{~kb}$ was used as a molecular marker. The dendrogram was generated in MEGA6 [24] using neighbor-joining [25], whereby evolutionary distances were assessed via the Tamura-Nei method [37] with gamma distribution as determined using the lowest Bayesian information criterion value. The final data set contained a total of 1124 positions (complete deletion option) and only bootstrap values $\geq 70$ (1000 replicates) are displayed at the nodes. Each sequence displayed the accession number, host species and originScale-bar: number of substitutions per nucleotide site

positive baitfish species collected $\left(F_{(2,54)}=6.6, P=0.003\right)$. The mean within lot prevalence was highest for the emerald shiners $(20.3 \pm 14.0 \%$; Table 1; Fig. 5), which was significantly greater than that for the golden shiners $(P=$ $0.02)$ and the sand shiners $(P=0.02)$, although the sample size was limited for the sand shiners $(n=3)$ and therefore reduced the power of the analysis. The mean within lot prevalence value for the golden shiner $(8.3 \pm 10.7 \%$; Table 1; Fig. 5) was higher than for the sand shiners $(1.3 \pm 2.6 \%$; Table 1; Fig. 5$)$, but did not differ significantly $(P=0.62)$.

Intensity, similar to prevalence, differed significantly among baitfish species examined during the course of this study $\left(F_{(2,54)}=4.3, P=0.019\right)$. The golden shiners had the highest mean intensity $(6.6 \pm 6.7$; Fig. 5$)$ which was significantly higher than the mean intensity in the sand shiners $(P=0.02)$, which had a mean of $0.3 \pm 0.7$. Although $S$. acheilognathi intensity was highest in the golden shiners, there was no significant difference when compared to the intensity found in the emerald shiners $(P=0.17)$. The emerald shiners had a mean intensity of $4.3 \pm 2.6$ (Fig. 5).

The abundance of $S$. acheilognathi did not differ significantly among the positive baitfish species collected $\left(F_{(2,54)}=1.46, P=0.24\right)$. The emerald shiners had the highest mean abundance (1.15 \pm 1.34 ; Fig. 5), but was only slightly greater than the golden shiners $(0.89 \pm 1.27)$ and the sand shiners $(0.02 \pm 0.05)$.

The three baitfish species that were infected with $S$. acheilognathi were emerald, golden and sand shiners from both in- and out-of-state sources. Specifically, the infested species from in-state sources were primarily lots of emerald shiner $(n=36)$ with some sand shiners $(n=3)$, while the out-of-state sources were predominantly lots composed of golden shiners $(n=28)$ and to a lesser extent emerald $(n=5)$ and sand $(n=1)$ shiners.

The source of where baitfish were originally collected in the wild significantly influenced the prevalence $\left(F_{(2,89)}=\right.$ 15.4, $P<0.01)$ and abundance $\left(F_{(2,89)}=4.6, P=0.01\right)$, but not the intensity $\left(F_{(2,89)}=2.2, P=0.12\right)$ of $S$. acheilognathi in the bait trade. Schyzocotyle acheilognathi prevalence and abundance were significantly greater for baitfish that were originally collected from in-state sources. Specifically, instate sources (i.e. originating from MI waters; $n=43$ ) had a mean within lot prevalence of $17.7 \%$ and abundance of 1.0 , whereas out-of-state sources (i.e. non-MI waters; $n=47$ ) had a mean within lot prevalence of only $3.5 \%$ and an abundance of 0.3. Two lots obtained were of unknown collection origin as the bait shops permanently closed before we conducted our follow-up communications to determine source.

\section{Discussion}

After invading North America in 1975 [10], it took a quarter century and 600 miles of distance for S. acheilognathi to be detected in the Great Lakes basin, where it was found in a single fathead minnow specimen from Peter Lake near the Wisconsin-Michigan border in 2001 [11]. Since this initial report, $S$. acheilognathi has expanded to several other sites in the Great Lakes basin, where it has been found 


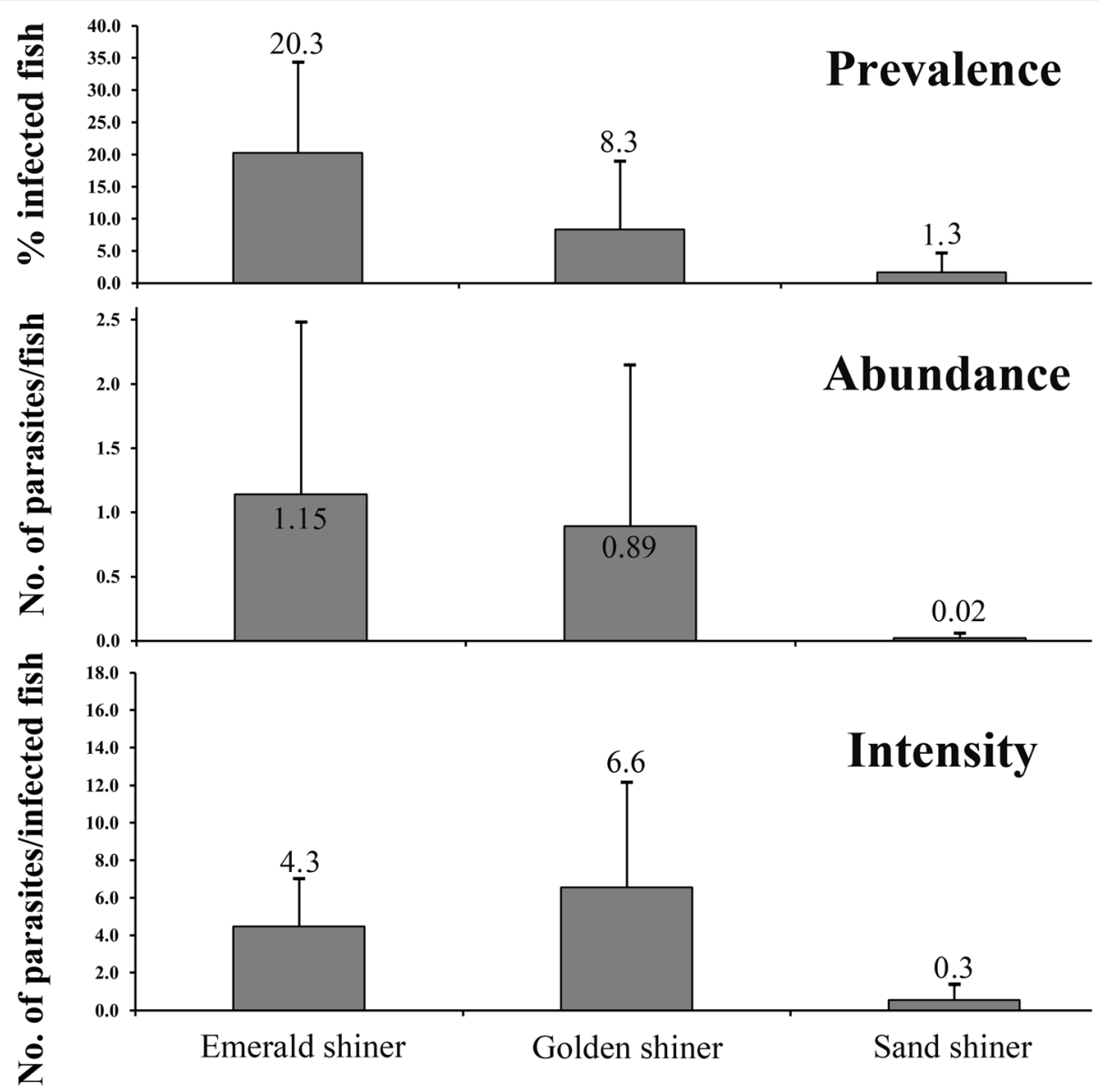

Fig. 5 Mean prevalence, mean abundance and mean intensity of Schyzocotyle acheilognathi infection in three baitfish species. Baitfish species emerald shiner (Notropis atherinoides), golden shiner (Notemigonus crysoleucas) and sand shiner (Notropis stramineus) were sampled from Michigan baitfish retail vendors

to infect emerald shiners, spottail shiners, mimic shiners [Notropis volucellus (Cope, 1865)], sand shiners, bluntnose minnows [Pimephales notatus (Rafinesque, 1820)] and common shiners [Luxilus cornutus (Mitchill, 1817)] [12, 16, 28]. This study is the most comprehensive study performed that inspects baitfish retail stores in North America in terms of the number of vendors, lots, and individual fish sampled and examined for the presence of S. acheilognathi. Our findings demonstrate that $S$. acheilognathi is present and widely distributed in cyprinid baitfish. Our findings indicate that the end of the trade custody chain (i.e. baitfish retail shops) represents a source for the potential introduction of S. acheilognathi via angler-purchased and potentially released baitfish.

Considering the ease with which $S$. acheilognathi can be disseminated due to its wide range of intermediate and definitive hosts, one would expect that $S$. acheilognathi will continue its expansion, not only in the Great Lakes, but also in inland lakes and waterways of Michigan. The potential increased risk in S. acheilognathi spread via the baitfish trade is indeed alarming, particularly because the pathological consequences of this worm can lead to intestinal inflammation, blockage, perforation, lack of absorption, and ultimately death [29-33]. Additionally, since 61 of the 159 fish species residing in the Great Lakes basin are threatened or endangered [34], an explosive expansion of a generalist parasite such as $S$. acheilognathi through the baitfish trade could exacerbate the tenuous status of the fish stocks at risk. In the same context, many important fish stock enhancement programs in the Great Lakes are fed with purchased baitfish from private sources in state and federal hatcheries prior to their stocking in public waters. This practice may expose these fish to a potentially lethal, debilitating parasite infections, and through widespread stocking of these fish, lead to further expansion into new geographic areas.

In this study, S. acheilognathi was detected in only three of eight cyprinids: emerald, golden and sand shiners. This finding, however, is, not a measurement of differential species susceptibility. For example, S. acheilognathi was found in fathead minnows by Choudhury et al. [11] and in spottail shiners by Muzzall et al. [12], whereas these two fish 
species were free of S. acheilognathi in our study. Emerald shiners had the highest prevalence of $S$. acheilognathi in our study, which coincides with the findings of Muzzall et al. [12] in wild emerald shiners collected from the southeastern region of Michigan. Macrogliese et al. [16] also observed S. acheilognathi prevalence to be the highest in emerald shiners collected from the wild and from six retail baitfish stores. Notably, the sum of these studies points to the emerald shiner as a suitable host to target in future $S$. acheilognathi surveillance studies. Likewise, the abundance of the golden shiner throughout the Great Lakes region, with wide distribution in both inland waters and the Great Lakes [35], makes this species suitable for monitoring the prevalence and spread of this invasive species in the Great Lakes basin. Golden shiners are particularly important in the imported baitfish trade and as such, would be important in conducting surveillance for S. acheilognathi in imported baitfish. The sand shiner could also be a good surveillance species to target based on a prevalence of $28 \%$ reported by Muzzall et al. [12].

\section{Conclusions}

We documented that the baitfish trade may be contributing to the expansion of $S$. acheilognathi in the Great Lakes basin. The high prevalence of $S$. acheilognathi in the retail bait shops combined with the high frequency of baitfish use among anglers results in a high risk for new introductions [4]. This risk is particularly elevated when considering that anglers have been documented to release unused baitfish at rates as high as $41 \%$ [36]. As such, there is a need for managerial intervention to abrogate or slow down the rate of this pathogen expansion. In Michigan, all baitfish imported from out-of-state or harvested from Michigan waters require a health certification for each pathogen concern, especially VHSv. The inclusion of $S$. acheilognathi as a pathogen of concern for baitfish health certification should be considered. Moreover, to reduce the risk of spreading this pathogen, baitfish should only be collected from sites continuously monitored to be free from $S$. acheilognathi. In addition to best management practices during collections, it is critical to enforce existing regulations that prohibit the dumping of unused baitfish back into public waters. Public educational campaigns should also complement enforcement actions to decrease the unused baitfish release behavior that is common among anglers. Based on our findings, we recommend a combination of increased surveillance, implementation of best management practices, additional enforcement, and an increased outreach campaign to ensure that $S$. acheilognathi does not spread further throughout the Great Lakes region via the baitfish trade.

\section{Acknowledgements}

We are grateful to the MDNR Fisheries Division staff (Emily Giuliano, Cheryl Benson, Ed Baker, Jan VanAmberg) and Lake Superior State University (Roger Greil) for assistance with baitfish collections.

\section{Funding}

This study was supported by Great Lakes Restoration Initiative funding provided to the Michigan Department of Natural Resources (grant no. F15AP00216) from the U.S. Fish and Wildlife service and subcontracted to Michigan State University (grant no. 751B5500047).

\section{Availability of data and materials}

The datasets used during the current study are available from the corresponding author on reasonable request. The sequences generated in this study were deposited in the GenBank database under the accession numbers KY711155-KY711166.

\section{Authors' contributions}

$\mathrm{TB}, \mathrm{MV}, \mathrm{TL}$ and MF were involved in the sampling, processing, analysis and interpretation of the data regarding the presence and confirmation of $S$. acheilognathi in the baitfish sampled. SH and GW were involved in the conception of the study, the design of the sampling plan, and the acquisition of samples. All authors have been involved in drafting the manuscript or revising it critically for important intellectual content, and have given final approval of the version to be submitted for publication. Each author agrees to be accountable for all aspects of the work in ensuring that questions related to the accuracy or integrity of any part of the work are appropriately investigated and resolved. All authors read and approved the final manuscript.

Ethics approval and consent to participate

All experiments were conducted in accordance with the ethical guidelines defined by Michigan State University's (MSU) Institutional Animal Care and Use Committee (AUF 09/15-138-00).

Consent for publication

Not applicable.

\section{Competing interests}

The authors declare that they have no competing interests.

\section{Publisher's Note}

Springer Nature remains neutral with regard to jurisdictional claims in published maps and institutional affiliations.

\section{Author details}

1Department of Pathobiology and Diagnostic Investigation, College of Veterinary Medicine, Michigan State University, East Lansing, Ml 48824, USA. ${ }^{2}$ Michigan Department of Natural Resources, Fisheries Division, Lansing, Ml 48933, USA. ${ }^{3}$ Department of Fisheries and Wildlife, College of Agriculture and Natural Resources, Michigan State University, East Lansing, MI 48824, USA.

Received: 15 June 2017 Accepted: 19 November 2017

Published online: 22 December 2017

\section{References}

1. Mills EL, Leach JH, Carlton JT, Secor CL. Exotic species in the Great Lakes: a history of biotic crises and anthropogenic introductions. J Great Lakes Res. 1993;19:1-54.

2. Mandrak N, Cudmore B. Fish species at risk and non-native fishes in the Great Lakes Basin: past, present, and future. In: Taylor W, Lynch A, Leonard $\mathrm{N}$, editors. Great Lakes fisheries policy and management: a binational perspective. East Lansing, USA: Michigan State University Press; 2013. p. $167-202$.

3. Kilian JV, Klauda RJ, Widman S, Kashiwagi M, Bourquin R, Weglein S, et al. An assessment of a bait industry and angler behavior as a vector of invasive species. Biol Invasions. 2012;14:1469-81.

4. Drake DAR, Mandrak NE. Bycatch, bait, anglers, and roads: quantifying vector activity and propagule introduction risk across lake ecosystems. Ecol Appl. 2014;24:877-94.

5. VHSv Expert Panel and Working Group. Viral hemorrhagic septicemia virus (VHSV IVb) risk factors and association measures derived by expert panel. Prev Vet Med. 2010;94:128-39.

6. Phelps NBD, Craft ME, Travis D, Pelican K, Goyal SM. Risk-based management of viral hemorrhagic septicemia virus in Minnesota. N Am J Fish Manage. 2014;34:373-9. 
7. Brabec J, Kuchta R, Scholz T, Littlewood DTJ. Paralogues of nuclear ribosomal genes conceal phylogenetic signals within the invasive Asian fish tapeworm lineage: evidence from next generation sequencing data. Int J Parasitol. 2016:46:555-62.

8. Scholz T, Kuchta R, Williams C. Bothriocephalus acheilognathi. In: Woo PTK, Buchmann K, editors. Fish parasites: pathobiology and protection. Wallingford: CAB International; 2012. p. 282-97.

9. Marcogliese DJ, Esch GW. Experimental and natural infection of planktonic and benthic copepods by the Asian tapeworm, Bothriocephalus acheilognathi. Proc Helminthol Soc Wash. 1989;56:151-5.

10. Hoffman GL. Parasites of north American freshwater fishes. 2nd ed. Ithaca: Comstock Publishing Associates; 1999.

11. Choudhury A, Charipar E, Nelson P, Hodgson JR, Bonar S, Cole RA. Update on the distribution of the invasive Asian fish tapeworm, Bothriocephalus acheilognathi, in the U.S. and Canada. Comp Parasitol. 2006;73:269-73.

12. Muzzall PM, Thomas MV, Whelan G. Occurrence of the Asian fish tapeworm, Bothriocephalus acheilognathi, in Notropis spp. (Cyprinidae) in Saginaw Bay and port Sanilac, Lake Huron, and Lake St. Clair, Michigan, U.S.A. Comp Parasitol. 2016:83:124-9.

13. Brouder MJ, Hoffnagle TL. Distribution and prevalence of the Asian fish tapeworm, Bothriocephalus acheilognathi, in the Colorado River and tributaries, grand canyon, Arizona, including two new host records. J Helminthol Soc Wash. 1997;64:219-26.

14. Choudhury A, Hoffnagle TL, Cole RA. Parasites of native and nonnative fishes in the little Colorado River, grand canyon, Arizona. J Parasitol. 2004;90:1042-53.

15. Choudhury A, Cole R. Bothriocephalus acheilognathi Yamaguti (Asian tapeworm). In: Francis RA, editor. A handbook of global freshwater invasive species. London: Earthscan; 2012. p. 389-404.

16. Marcogliese DJ, Gendron AD, Forest JJH, Li W, Boyce K, El-Shehabi F, et al. Range expansion and molecular confirmation of the Asian fish tapeworm in the lower Great Lakes and St. Lawrence River with notes on infections in baitfish. J Great Lakes Res. 2016;42:819-28.

17. Michigan Department of Natural Resources. Fishing in Michigan: commercial bait industry, Annual Commercial Catch \& Value. 2017. http://www.michigan.gov /dnr/0,4570,7-153-10364_52261_76797386182-,00.html. Accessed 2 Mar 2017.

18. USFWS and AFS-FHS (U.S. Fish and Wildlife Service and American Fisheries Society-Fish Health Section). AFS-FHS. FHS Blue Book: Suggested procedures for the detection and identification of certain finfish and shellfish pathogens, 2016 ed. 2016. http://afs-fhs.org/bluebook/bluebook-index.php. Accessed 2 Mar 2017.

19. Scholz TA. Revision of the species of Bothriocephalus Rudolphi, 1808 (Cestoda: Pseudophyllidea) parasitic in American freshwater fishes. Syst Parasitol. 1997;36:85-107.

20. Luton K, Walker D, Blair D. Comparisons of ribosomal internal transcribed spacers from two congeneric species of flukes (Platyhelminthes: Trematoda: Digenea). Mol Biochem Parasit. 1992;56:323-8.

21. Luo HY, Nie P, Zhang YA, Wang GT, Yao WJ. Molecular variation of Bothriocephalus acheilognathi Yamaguti, 1934 (Cestoda: Pseudophyllidea) in different fish host species based on ITS rDNA sequences. Syst Parasitol. 2002;52:159-66

22. Hall TA. BioEdit: a user-friendly biological sequence alignment editor and analysis program for windows 95/98/NT. Nucl Acids Symp Series. 1999;41:95-8.

23. Altschul SF, Gish W, Miller W, Myers EW, Lipman DJ. Basic local alignment search tool. J Mol Biol. 1990;215:403-10.

24. Tamura K, Stecher G, Peterson D, Filipski A, Kumar S. MEGA6: Molecular evolutionary genetics analysis version 6.0. Mol Biol Evol. 2013;30:2725-9.

25. Saitou N, Nei M. The neighbor-joining method: a new method for reconstructing phylogenetic trees. Mol Biol Evol. 1987;4:406-25.

26. Bush AO, Lafferty KD, Lotz JM, Shostak AW. Parasitology meets ecology on its own terms: Margolis et al. revisited. J Parasitol. 1997:83:575-83.

27. Zar JH. Biostatistical analysis. New York: Prentice-Hall; 1999.

28. Marcogliese DJ. First report of the Asian fish tapeworm in the Great Lakes. J Great Lakes Res. 2008;34:566-9.

29. Liao H, Shih L. Contribution to the biology and control of Bothriocephalus gowkongensis Yeh, a tapeworm parasitic in the young grass carp (Ctenopharyngodon idellus C. and V.). Acta Hydrobiol Sin. 1956;2:129-85.

30. Hoole D, Nisan H. Ultrastructural studies on intestinal response of carp, Cyprinus carpio L., to the pseudophyllidean tapeworm, Bothriocephalus acheilognathi Yamaguti, 1934. J Fish Dis. 1994;17:623-9.
31. Hansen SP, Choudhury A, Heisey DM, Ahumada JA, Hoffnagle TL, Cole RA. Experimental infection of the endangered bonytail chub (Gila elegans) with the Asian fish tapeworm (Bothriocephalus acheilognathi): impacts on survival, growth, and condition. Can J Zool. 2006;84:1383-94.

32. Koehle JJ, Adelman IR. The effects of temperature, dissolved oxygen, and Asian tapeworm infection on growth and survival of the Topeka shiner. T Am Fish Soc. 2007:136:1607-13.

33. Britton JR, Pegg J, Williams CF. Pathological and ecological host consequences of infection by an introduced fish parasite. PLoS One. 2011;6: 0026365.

34. GLFC (Great Lakes Fishery Commission). Great Lakes fishery commission. 2017. http://www.glfc.org/the-fishery.php. Accessed 5 Dec 2017.

35. Becker GC. Fishes of Wisconsin. Madison: University of Wisconsin Press; 1983.

36. Kulwicki MM, Rosenthal SK, Lodge DM. Aquatic nuisance species awareness of anglers in northern Wisconsin and the upper peninsula of Michigan. 12th International Conference on Aquatic Invasive Species. Windsor, Ontario, 9-12 June 2003, Abstracts, p. 139. Ottawa, Ontario: The Professional Edge.

37. Tamura K, Nei M. Estimation of the number of nucleotide substitutions in the control region of mitochondrial DNA in humans and chimpanzees. Mol Biol Evol. 1993;10:512-26.

\section{Submit your next manuscript to BioMed Central and we will help you at every step:}

- We accept pre-submission inquiries

- Our selector tool helps you to find the most relevant journal

- We provide round the clock customer support

- Convenient online submission

- Thorough peer review

- Inclusion in PubMed and all major indexing services

- Maximum visibility for your research

Submit your manuscript at www.biomedcentral.com/submit
C) Biomed Central 